\title{
娄 \\ Impact of the Accounting Information System on Corporate Governance: Evidence from Turkish Non-Listed Companies
}

\author{
Ali Uyar ${ }^{1}$, Ali Haydar Gungormus ${ }^{2}$ and Cemil Kuzey ${ }^{3}$
}

\begin{abstract}
Corporate scandals in the early 2000s have demonstrated how accounting and auditing failures, together with the abuses of managers have the ability to create major problems. In order to avoid future scandals, this study investigates the association between the accounting information system and corporate governance. We hope that these findings will contribute towards the enhancement of good corporate governance created by the accounting function of business organizations. The results of empirical analyses indicate that bookkeeping, financial reporting, and the budgeting system have a positive impact on the corporate governance level, whereas the adoption of Turkish Accounting / Financial Reporting Standards do not. Thus, in order to foster corporate governance, managers should establish internal reporting procedures as well as internal control and monitoring devices before attempting external control through independent auditing.
\end{abstract}

JEL Classification: M40, G34.

Keywords: Accounting information system, bookkeeping, financial reporting, accounting standards, corporate governance, management accounting, Turkey.

\footnotetext{
${ }^{1}$ College of Business Administration, American University of the Middle East, Egaila, Kuwait Block 3, Building 1, Egaila, 15453, Kuwait. aliuyar@hotmail.com

${ }^{2}$ Independent Scholar, Istanbul, Turkey. a.h.gungormus@gmail.com

${ }^{3}$ Murray State University, Arthur J, Bauernfeind College of Business, Computer Science/ Information Systems, Murray, KY 42071, United States

cemilkuzey@gmail.com
} 


\section{Introduction}

Corporate scandals (i.e. Enron, Tyco, and WorldCom) in the early 2000s have demonstrated how accounting and auditing failures have resulted in corporate failures, destroying investor confidence, and harming capital markets. In response to these corporate accounting scandals, the U.S. Congress passed the Sarbanes-Oxley Act (SOX) in 2002, to protect investors from possible future scandals as well as to prevent fraudulent financial reporting by companies. In fact, these corporate failures are not peculiar to just one country or a geographical region, and they are not limited to a time frame; they occur in various countries at varying time intervals, as past harsh experiences have shown. A quick Google search produces a comprehensive list of such scandals across countries and intervals. In the context of Australia, Garry et al. (2014) reported that these corporate scandals were cyclical over four rounds of corporate failures (i.e. early 1960s, late 1980s, early 1990s and the early 2000s), and that these corporate scandals were followed by a series of changes in governance (i.e. legislative reforms relating to financial reporting or auditing) to prevent their recurrence. For example, in response to the crisis in the early 2000s, the Corporate Law Economic Reform Program (Audit Reform and Corporate Disclosure) Act 2004 Cwlth (CLERP 9 Act 2004) was enacted, which included increased disclosure requirements, tightened requirements for continuous disclosure, enhanced accountability, increased penalties for non-compliance, and increased auditors' independence (Australian Securities and Investments Commission, 2012).

The adoption of corporate governance principles and the enactment of regulations to improve investor confidence in the marketplace were hastily put into place all around the world. Good governing practices are particularly important for emerging countries, since they need external funds to finance investments. Foreign investors are inclined to prefer countries that promise good investment opportunities and also an attractive investment environment such as appropriate regulations, transparency and accountability. In order to access international financing resources, Turkey must also provide quality financial information to stakeholders (Alp \& Ustundag, 2009).

For this reason, regulations were enacted regarding corporate governance practices by the Capital Markets Board: The International Accounting/Financial Reporting Standards (TAS/TFRS) were adopted, a new Turkish Commercial Code was enacted, and the Corporate Governance Index was established by the Borsa Istanbul (formerly known as the Istanbul Stock Exchange). The purpose of these regulations and initiatives is to build a stronger, trustworthy, transparent business environment that confidently attracts investors. The recent worldwide corporate scandals have demonstrated that the proper functioning of accounting information system is crucial for improving governance in business organizations, since it produces primary financial reports utilized by stakeholders including investors, creditors and others. Although voluntary disclosures play a role in the decisions of investors, creditors, and other stakeholders, mandatory financial reports remain the primary tools for investing decisions particularly. Thus, the quality and reliability of information presented in financial reports is crucial to these stakeholders. A well-functioning accounting information system (AIS), free from fraud, is likely to improve the corporate governance level in organizations, build a better business world, improve investor confidence, and assist the efficiency of capital markets.

Corporate governance and accounting are interconnected with each other on the basis of the two principles of transparency and accountability. The effectiveness of the AIS is expected to strengthen governance mechanisms leading to the efficient functioning of capital markets. AIS 
provides the information that flows from firm to stakeholders continuously. This flow of information forms the basis for the decision making of the stakeholders. For example, periodical financial reports are the primary tools of investors which enable the buying, holding, or selling decisions connected to shares. Therefore, the published periodical financial reports are expected to be relevant, faithfully represented, comparable, verifiable, timely, and comprehensible (EY, 2010).

Shil (2008) considered accounting to be a vehicle that ensures good corporate governance, and also that accounting may be practiced in such a way that corporate governance can be maintained. The author further explained how accounting can alleviate agency problems and resolve conflicts between various stakeholders. Collins and DeAngelo (1990) also pointed out the role of accounting in corporate governance through which managerial inefficiency is detected and punished. In recent years, research regarding the association between accounting and corporate governance has largely been based upon disclosure studies (Haniffa \& Cooke, 2002; Eng \& Mak, 2003; Tsamenyi et al., 2007; Bokpin \& Isshaq, 2009; Uyar, 2012). This study aims at investigating the impact of the AIS on corporate governance. We have particularly focused on four attributes of AIS, namely: bookkeeping, the efficacy of financial reporting, the adoption of the Turkish Accounting/Financial Reporting Standards, and the efficacy of the budgeting system. These four attributes address different aspects of AIS. For example, bookkeeping refers to the recording function; financial reporting refers to the external reporting function; standards refer to the framework for the accounting practices; and finally, the efficacy of the budgeting system addresses the planning and controlling function. In prior studies, the role of financial reporting in corporate governance was prominently investigated (Naumann, 2000; Bushman \& Smith, 2001; Sloan, 2001; Bushman et al., 2004; Kalbers, 2009); however, we cannot say the same thing for management accounting practices. Thus, we aim at filling this gap by operationalizing the budgeting system as one of the primary management accounting tools.

The remainder of the paper is organized as follows. The next section provides a literature review and formulates the hypotheses. The third section provides the methodology of the study. The fourth section analyzes the results, and the final section concludes the paper by providing implications.

\section{Literature review and hypotheses}

\section{Bookkeeping system}

The everyday recording of financial transactions by accountants in the accounting information system is called double-entry bookkeeping (Nobes \& Stadler, 2013). Bookkeeping, which helps organize and classify business transactions, plays a fundamental role in accounting practices and financial reporting. It is the initial process which provides data for further accounting applications. Mistakes or fraud in bookkeeping has a domino effect on other practices; thus, the reliability of financial reports is closely connected to the appropriate bookkeeping practices. If, either intentionally or accidentally, bookkeepers make inappropriate recordings, this results in falsified financial statements and they lose their usefulness and efficiency in both internal and external decision-making.

Therefore, we formulate the following hypothesis:

\section{H1. The effective use of the bookkeeping system impacts corporate governance positively.}




\section{Financial reporting}

The corporate reporting process has become very dynamic in the last two decades due to an increase in demand for both financial and non-financial information by stakeholders. Although non-financial information disclosure has undergone tremendous change and improvement, financial reports are fundamental, particularly for those with financial interests in corporations, such as investors, creditors, and tax authorities. They present information regarding the financial position, performance, changes in stockholders' equity, and cash flow of a company relating to a specific date or period. Financial reports are prepared in accordance with accounting principles and financial reporting standards to enable a comparison across the years as well as various companies and industries. Directors are responsible for disseminating reliable information concerning the financial position of the company to investors; as well, they oversee, supervise and monitor the financial reporting process of the company as prepared by their accountants (Pallisserry, 2012). However, masking the real financial position of the company due to error or fraud leads to corporate failures (Pallisserry, 2012). One quality characteristic of financial reports is objectivity; Abraham et al. (2008) asserted that the subjectivity of financial reports threatens their usefulness and reliability across all industry sectors. The lack of reliability in financial reports is attributable to a deficiency in the people involved in preparing and monitoring the reports, such as board members and accounting personnel; a deficiency in the nature of accounting standards; a deficiency in the regulatory system; or a combination of any of these (Abraham et al., 2008). Hence, the quality of financial information presented in financial reports, and the effective use of reports by managers is expected to improve corporate governance positively. Therefore, we develop the following hypothesis:

\section{H2. The effective use of financial reporting in decision-making impacts corporate governance positively.}

\section{Turkish Accounting Standards/Turkish Financial Reporting Standards (TAS/TFRS)}

As with every aspect of business practice, accounting practices are going global. The trend is to converge accounting and/or financial reporting standards so that capital can flow more freely in global markets. The convergence of standards helps to make the financial reports of firms comparable from country to country; thus, allowing the boundaries that restrict investors to disappear. The importance of accounting standards, which are aimed at providing high quality, dependable, comparable, and comprehensible financial information, are recognized around the world (Alp and Ustundag, 2009). As a result, globally accepted financial reporting standards are vital to various stakeholders such as investors, creditors, financial analysts, and any others that utilize financial statements in their decision-making (Ankarath et al., 2010). In the literature, the advantages of using a common set of accounting or financial reporting standards are listed as improved efficiency and effectiveness in financial reporting and auditing (Joshi \& Ramadhan, 2002; Uyar \& Güngörmüş, 2013; Kılıç et al., 2014); enhanced comparability (Epstein \& Jermakowicz, 2007; Jeanjean \& Stolowy, 2008; Jones \& Finley, 2011; Uyar \& Güngörmüş, 2013; Kılıç et al., 2014); and greater transparency and reliability (Ball, 2006; Dumontier \& Raffournier, 1998; Neag et al., 2009; Madawaki, 2012; Uyar \& Güngörmüş, 2013; Kılıç et al., 2014). These advantages are closely tied to the corporate governance mechanism, and are 
Uyar, Gungormus \& Kuzey | Impact of the Accounting Information System on Corporate Governance: Evidence from Turkey

expected to contribute to good governance practices. Therefore, we formulate the following hypothesis:

\section{H3. The use of TAS/TFRS impacts corporate governance positively.}

Turkey is one of the countries which have adopted the International Accounting Standards and the International Financial Reporting Standards (Uyar et al., 2016); the standards have been named the Turkish Accounting Standards (TAS) and the Turkish Financial Reporting Standards (TFRS).

\section{Budgeting system}

In addition to the responsibilities of external monitors such as auditors and regulators, management accounting plays an important role in the execution of good corporate governance through internal reporting and monitoring (Seal, 2006), and providing timely and relevant information (Mayanja \& Van der Poll, 2011). Recently, Wang and Huynh (2014) provided empirical evidence for the association between management accounting and corporate governance. Budgeting is a primary tool of management accounting, used as a planning and internal controlling device by business organizations (Uyar \& Kuzey, 2016). Thus, the process of budgeting should not be considered routine. Many prior studies have demonstrated that companies still use it as an indispensable tool for managerial decision making. As well as setting targets, at the same time, it limits the boundaries of managers for discretionary expenditures. At the end of the stated period, it is then used as a check-and-control device, based upon the calculation of variances. Hence, an effective budgeting system contributes to corporate governance by not allowing managers to misuse the financial resources of firms and by setting the better allocation of resources. Therefore, we formulate the following hypothesis:

\section{H4. The efficacy of the budgeting system impacts corporate governance positively.}

\section{Research Methodology}

Sample

The sample for the study consisted of firms operating in Istanbul. Approximately 2,600,000 businesses currently operate in Turkey. The majority, 2,500,000, are considered to be "microbusinesses" that only employ between 1 to 9 employees, and have lower than a 1 million TRY annual turnover. Businesses with a 1 to 8 million TRY annual turnover employing $20-50$ workers are defined as "small-scale enterprises". There are approximately 46,000 small-scale enterprises. The businesses with an 8 to 40 million TRY annual turnover are classified as medium-sized businesses, of which there are 19,500 in Turkey (Güngörmüş, 2014).

Since it would be very difficult to access the population due to financial and technical difficulty in Turkey, Istanbul was selected as the target population. Istanbul was chosen because a large proportion of the firms are located there, and the results of studying these firms would provide a template for all of Turkey.

We contacted non-governmental business organizations, obtaining contact information of their members. This information assisted with communication with the firms, either through telephone calls or electronic mail. The research covers the SMEs and their managers located in Istanbul. 
The ethical concerns that were identified before starting the survey were carefully considered. Procedures, safety and confidentiality, as well as permission issues were expressed in writing on the questionnaire as well as conveyed orally to the managers, so that they were adequately informed concerning the objectives of the research.

The survey was distributed to general managers, assistant general managers, directors of financial affairs, and those with similar titles of the firms. Questionnaires with a large proportion of unanswered questions were excluded from the analysis. We administered a questionnaire survey to collect the data. The data were collected by direct interviews with the managers, by online survey, and by telephoning the firms whose addresses were retrieved from business associations. In total, we contacted 400 firms, out of which 142 responded to the survey, yielding a response rate of $35.5 \%$. A simple random sampling method was employed. In order to test the hypothetical association of the model in this study, the PLS-SEM method was employed. For this approach, 10 items per latent variables are sufficient (Hair et al., 2013). In the research model, seven latent variables existed which indicated that the sample size was sufficient. The questionnaire, which consisted of demographics and two sections, was constructed based upon prior studies (see Appendix). The section regarding their accounting information system was based on Dinç and Varıcı (2008), Acar and Özçelik (2011), and Dinç and Abdioğlu (2009). The corporate governance construct was formed based upon Alpay et al. (2008).

As the research methodology, CB-SEM was utilized. This estimates the coefficients of a set of equations by adjusting the covariance matrix. This model is required to satisfy the multivariate normality assumption as well as requiring a larger sample size. On the other hand, the PLS approach estimates the coefficients of a set of equations by applying the partial least squares method. This does not require the hard normality restriction or a large sample size. Partial Least Square Structural Equation Modeling (PLS-SEM) was used in this study rather than the Covariance-Based Structural Equation Modeling (CB-SEM) approach, since the sample size was small (142). The proposed model is illustrated in Figure 1.

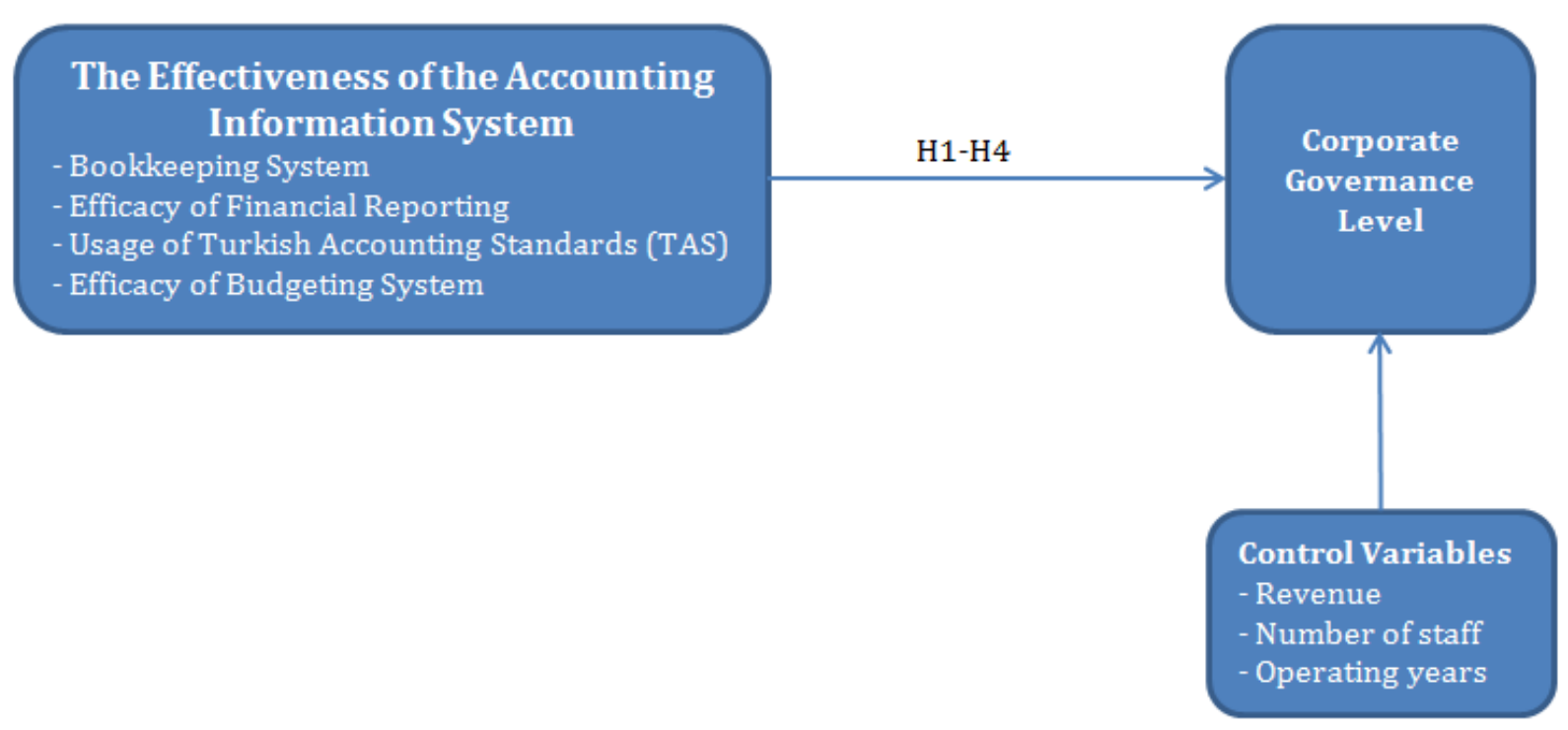

Figure 1: Proposed Model 
Uyar, Gungormus \& Kuzey | Impact of the Accounting Information System on Corporate Governance: Evidence from Turkey

\section{Descriptive statistics:}

The descriptive statistical values of staff size, number of operating years, sectors for providing service, revenue, number of senior managers, and education level are shown in Table 1. The results indicated that $32.4 \%$ of the surveyed firms had a staff numbering between 10 and 49 members, that $53.5 \%$ of the firms had been operating for about 20 years, that almost half of the firms provided service in the domestic market, that $31 \%$ had an annual revenue between 1 million and 8 million (TRY), and that $42.3 \%$ of the firms included some level of undergraduate education amongst their administrators. In addition, $31.7 \%$ of the firms did not have professional senior managers, meaning that only family members make decisions at the top level of the firm.

Table 1: Descriptive statistics

\begin{tabular}{|c|c|c|}
\hline & Frequency & Percent \\
\hline \multicolumn{3}{|l|}{ Number of staff members: } \\
\hline $0-9$ & 31 & 21.8 \\
\hline $10-49$ & 46 & 32.4 \\
\hline $50-99$ & 22 & 15.5 \\
\hline $100-249$ & 27 & 19.0 \\
\hline 250 over & 16 & 11.3 \\
\hline Total & 142 & 100.0 \\
\hline \multicolumn{3}{|l|}{ Operating years: } \\
\hline Less than 10 years & 35 & 24.6 \\
\hline $10-19$ years & 41 & 28.9 \\
\hline $20-29$ years & 31 & 21.8 \\
\hline $30-39$ years & 21 & 14.8 \\
\hline 40 over years & 14 & 9.9 \\
\hline Total & 142 & 100.0 \\
\hline \multicolumn{3}{|l|}{ Sector providing service: } \\
\hline Only domestic market & 62 & 43.7 \\
\hline Only international market & 8 & 5.6 \\
\hline Both & 72 & 50.7 \\
\hline Total & 142 & 100.0 \\
\hline \multicolumn{3}{|l|}{ Revenue: } \\
\hline Less than $1.000 .000 \mathrm{TRY}^{*}$ & 27 & 19.0 \\
\hline 1.000.000-8.000.000TRY & 44 & 31.0 \\
\hline 8.000.001-40.000.000TRY & 30 & 21.1 \\
\hline 40.000.001-80.000.000TRY & 17 & 12.0 \\
\hline 80.000.001-100.000.000TRY & 6 & 4.2 \\
\hline 100.000 .001 over & 18 & 12.7 \\
\hline Total & 142 & 100.0 \\
\hline \multicolumn{3}{|c|}{ Number of senior managers outside family members: } \\
\hline None & 45 & 31.7 \\
\hline $1-3$ & 55 & 38.7 \\
\hline $4-6$ & 22 & 15.5 \\
\hline $7-9$ & 11 & 7.7 \\
\hline 10 over & 9 & 6.3 \\
\hline Total & 142 & 100.0 \\
\hline \multicolumn{3}{|l|}{ Education level: } \\
\hline Primary school & 10 & 7.0 \\
\hline High school & 33 & 23.2 \\
\hline College & 25 & 17.6 \\
\hline Undergraduate & 60 & 42.3 \\
\hline Post graduate & 14 & 9.9 \\
\hline Total & 142 & 100.0 \\
\hline
\end{tabular}

* Turkish liras (TRY) 


\section{Factor Loadings:}

Factor loading values based on PLS are shown in Table 2. There were five factors as well as three control variables. The latent variables were the effectiveness of the accounting information system (four sub-dimensions, being the bookkeeping system, the efficacy of financial reporting, the adoption of the Turkish Accounting Standards, and the efficacy of the budgeting system), as well as the corporate governance level. In addition, revenue, the number of staff members, and the number of years of operation by the firms were control variables. The selection of these control variables was based on prior works (Alpay et al., 2008; Afrifa \& Tauringana, 2015; Arora \& Sharma, 2016; Chen et al., 2016; Arunruangsirilert \& Chonglerttham, 2017). Firm sizes, as measured by revenue and staff numbers, are expected to influence corporate governance positively, since larger firms tend to have a larger amount of resources to commit to the establishment of good corporate governance structure. On the other hand, firm longevity, as measured by the number of operating years, is assumed to also impact corporate governance structure. There were 17 items left after eliminating some items from the analysis, since they had a factor loading lower than the threshold value of .7. The value of factor loadings is recommended to be higher than the cross-loading value along each construct column. As well, they should have a higher relationship with the latent variable column than with any other variable column (Chin, 1998). Discriminant validity was also assessed when the study items had higher loading values on their own latent variables than on other variables.

Table 2: Factor Loadings

\begin{tabular}{lrrrrrrrr}
\hline & BKS & FR & TAS & BS & CGL & OY & RVN & NSTFF \\
\hline BKS1 & $\mathbf{. 8 9 9}$ & .670 & .463 & .654 & .688 & .127 & .315 & .290 \\
BKS3 & $\mathbf{. 8 4 2}$ & .618 & .474 & .598 & .641 & .191 & .360 & .314 \\
BKS4 & $\mathbf{. 8 7 5}$ & .705 & .506 & .660 & .731 & .133 & .328 & .273 \\
FR1 & .682 & .914 & .603 & .714 & .737 & .188 & .418 & .425 \\
FR2 & .739 & $\mathbf{. 9 3 8}$ & .641 & .751 & .771 & .190 & .385 & .385 \\
FR3 & .660 & $\mathbf{. 8 7 4}$ & .580 & .715 & .712 & .145 & .332 & .347 \\
TAS1 & .461 & .554 &. $\mathbf{9 0 8}$ & .508 & .515 & -.055 & .159 & .155 \\
TAS2 & .550 & .672 & $\mathbf{. 9 3 6}$ & .648 & .614 & .069 & .349 & .321 \\
BS1 & .451 & .527 & .512 & $\mathbf{. 7 5 3}$ & .490 & .072 & .311 & .403 \\
BS2 & .722 & .790 & .620 & $\mathbf{. 9 3 2}$ & .741 & .211 & .454 & .377 \\
BS3 & .713 & .754 & .534 & $\mathbf{. 9 3 7}$ & .695 & .215 & .406 & .379 \\
CG11 & .610 & .648 & .497 & .606 & $\mathbf{. 8 4 3}$ & .142 & .491 & .448 \\
CG15 & .653 & .644 & .477 & .590 & $\mathbf{. 8 2 2}$ & .047 & .289 & .234 \\
CG17 & .686 & .699 & .526 & .629 & $\mathbf{. 8 7 0}$ & .044 & .392 & .290 \\
CG5 & .674 & .758 & .536 & .725 & $\mathbf{. 8 5 4}$ & .180 & .320 & .416 \\
CG6 & .691 & .719 & .593 & .632 & $\mathbf{. 8 6 7}$ & .162 & .423 & .441 \\
CG9 & .730 & .703 & .525 & .629 & $\mathbf{. 8 7 4}$ & .080 & .400 & .399 \\
OY & .171 & .192 & -.067 & .199 & .129 & $\mathbf{1 . 0 0 0}$ & .142 & .208 \\
RVN & .382 & .416 & .284 & .451 & .451 & .142 & $\mathbf{1 . 0 0 0}$ & .524 \\
NSTFF & .334 & .424 & .265 & .433 & .436 & .208 & .524 & $\mathbf{1 . 0 0 0}$ \\
\hline
\end{tabular}

Notes: BKS: Bookkeeping system; FR: Efficacy of Financial reporting; TAS: Adoption of Turkish Accounting Standards; BS: Efficacy of the Budgeting System; CGL: Corporate Governance Level; OY: Number of operating years; RVN: Revenue; NSTFF: Number of staff members 
Uyar, Gungormus \& Kuzey | Impact of the Accounting Information System on Corporate Governance: Evidence from Turkey

\section{Confirmatory factor analysis:}

The reliability as well as the validity of the variables were assessed by using confirmatory factor analysis (CFA) as recommended by Fornell and Larcker (1981) and Anderson and Gerbing (1988). Following the data collection, the constructs were subjected to CFA in order to test the construct validity and the model fit of the research model, using the maximum likelihood method. Some of the metrics used for the goodness of fit are chi-square/df, comparative fit index (CFI), goodness of fit index (GFI), adjusted goodness of fit index (AGFI), standardized root mean square residual (SRMR), and root mean square error of approximation (RMSEA). The threshold values for some of the fit metrics are chi-square/df $<3$, CFI $>.90$, GFI $>.95$ (.90 is permissible), AGFI $>.80$, SRMR<.09, RMSEA<.05, and PCLOSE $>.05$ (Bagozzi and Yi, 1988; $\mathrm{Hu}$ and Bentler, 1999). The CFA results are shown in Table 3. The results indicated that: Chisquare was $144.93(\mathrm{p}<.01)$, Chi-square/df was 1.39 , the goodness of fit index was .90 , the adjusted goodness of fit index was .85, the comparative fit index was .98 , the incremental fit index was .98 , the Tucker-Lewis index was .97 , the root mean square error of approximation was .05 , the value of PCLOSE was .40 , and the standardized root mean residual was .03 . The fit indices proved that they were above the recommended threshold values. Therefore, the model fit was satisfied, and the soundness of the measurement properties was confirmed.

\section{Measurement model analysis:}

Reflective versus formative: Reflective indicators for each construct were used since the direction of causality is from construct to assessment; therefore, the elimination of an indicator from the model does not affect the construct measures (Jarvis et al., 2003).

Validity and Reliability: Discriminant validity, internal consistency, and individual item reliability are necessary to investigate the measurement model analysis (Hair et al., 2010). For this purpose, the maximum-shared variance (MSV), the average-shared variance (ASV), the average variance extracted (AVE), the composite reliability (CR), and the Pearson correlation coefficients with the square root of AVE values were calculated (Table 3). Individual item reliability was related to the factor loadings of the indicators. Factor loadings of .70 were the threshold values, therefore all items above the threshold values were included in the analysis, while items lower than .7 were eliminated. It is clear from Table 3 that the reliability of the measurement model was satisfied. Internal consistency was assessed using the values of Cronbach's alpha as well as composite reliability. The suggested threshold value for CR is .70 (Nunnally, 1978). The Cronbach's alpha of the construct values ranged between .826 and .926 which were well above the suggested value of .7 while the CR values ranged between .905 and .942 , which were also well above the threshold value of .7. In addition, the discriminant validity was determined by using AVE scores (Fornel and Larcker, 1981), and MSV and ASV values (Hair et. al, 2010), as well as comparing the square root of AVE values with the correlation coefficients. The discriminant validity showed that the given construct was different from the rest of the constructs. In order to prove this fact, the values of AVE should be above the threshold value of .5, the values of MSV and ASV should be lower than the values of AVE for each construct, and the square root of AVE scores on the diagonal of the correlation matrix should be higher than the correlation coefficients of the rest of the construct in the column and row levels. The results showed that the AVE values were higher than the MSV and ASV scores, that the square root of the AVE values was higher than the correlation coefficients at the column and row levels, and finally, that the values of AVE ranged between .731 and .851 which were 
well above the benchmark value of .5. In conclusion, these results revealed that the study did not show that there was a discriminant validity issue.

Table 3: Correlation coefficients and reliability analysis results

\begin{tabular}{llllllllllllll}
\hline Constructs & AVE & CR & $\alpha$ & MSV & ASV & $\mathbf{1}$ & $\mathbf{2}$ & $\mathbf{3}$ & $\mathbf{4}$ & $\mathbf{5}$ & $\mathbf{6}$ & $\mathbf{7}$ & $\mathbf{8}$ \\
\hline 1)BKS & .761 & .905 & .843 & .623 & .333 & $\mathbf{. 8 7 2}$ & & & & & & \\
2)FR & .827 & .935 & .895 & .663 & .389 & $.764^{* *}$ & $\mathbf{. 9 0 9}$ & & & & & \\
3)TAS & .851 & .919 & .826 & .448 & .241 & $.552^{* *}$ & $.669^{* *}$ & $\mathbf{. 9 2 2}$ & & & & \\
4)BS & .771 & .909 & .849 & .639 & .365 & $.732^{* *}$ & $.799^{* *}$ & $.633^{* *}$ & $\mathbf{8 7 8}$ & & & \\
5)CGL & .731 & .942 & .926 & .663 & .376 & $.789^{* *}$ & $.814^{* *}$ & $.616^{* *}$ & $.744^{* *}$ & $\mathbf{. 8 5 5}$ & & \\
6)OY & 1.000 & 1.000 & 1.000 & .043 & .027 & $.171^{*}$ & $.192^{*}$ & -.067 & $.199^{*}$ & .129 & NA & \\
7)RVN & 1.000 & 1.000 & 1.000 & .274 & .157 & $.382^{* *}$ & $.416^{* *}$ & $.284^{* *}$ & $.451^{* *}$ & $.451^{* *}$ & .142 & NA & \\
8)NSTFF & 1.000 & 1.000 & 1.000 & .274 & .151 & $.334^{* *}$ & $.424^{* *}$ & $.265^{* *}$ & $.433^{* *}$ & $.436^{* *}$ & $.208^{*}$ & $.523^{* *}$ & NA \\
\hline
\end{tabular}

Notes: BKS: Bookkeeping system; FR: Efficacy of Financial reporting; TAS: Adoption of Turkish Accounting Standards; BS: Efficacy of the Budgeting System; CGL: Corporate Governance Level; OY: Number of operating years; RVN: Revenue; NSTFF: Number of staff members; CR: Composite reliability, $\alpha$ : Cronbach's Alpha, MSV: maximum-shared variance, ASV: average shared variance, AVE: average variance extracted;

CFA results: Chi-square $=144.93, p<.01 ;$ Chi-squareldf=1.39; GFI=.90; $A G F I=.85 ; C F I=.98 ; I F I=.98 ; T L I=.97$; RMSEA=.05; PCLOSE=.40; SRMR=.03

$* * p<.01 ; * p<.05$

\section{Structural Equation Modeling}

Predictive power: The SEM with PLS approach was applied to test the hypothesized relationships as well as the validity of the proposed model. As suggested by Chin (1998), the bootstrapping with 5000 resampling method was employed to test the statistical significance of the path. The path coefficients and the directions, as well as their significance level between the latent variables are illustrated in Table 4 and Figure 2. The SEM results indicated that there was a highly significant positive association between the bookkeeping system and the corporate governance level at a $1 \%$ significance level $(\beta=.36, \mathrm{p}<.01)$; the efficacy of financial reporting and the corporate governance level at a $1 \%$ significance level $(\beta=.33, \mathrm{p}<.01)$; and efficacy of the budgeting system and the corporate governance level at a $5 \%$ significance level $(\beta=.22$, $\mathrm{p}<.05)$. However, the use of the Turkish Accounting/Financial Reporting Standards did not show a statistically significant relationship with the corporate governance level at $5 \%$. Thus, the path analysis results indicated that $\mathrm{H} 1, \mathrm{H} 2$, and $\mathrm{H} 4$ were supported, but $\mathrm{H} 3$ was not.

Table 4: Structural Equation modeling results

\begin{tabular}{llllrrr}
\hline Hypothesized relationships & & & Coefficients & t-statistics & Results \\
\hline $\mathrm{H} 1$ & BKS & $\rightarrow$ & CGL & $.3589 * * *$ & 5.338 & Supported \\
H2 & FR & $\rightarrow$ & CGL & $.3262 * * *$ & 3.399 & Supported \\
H3 & TAS & $\rightarrow$ & CGL & .051 & .998 & Not Supported \\
H4 & BS & $\rightarrow$ & CGL & $.2205 * *$ & 2.275 & Supported \\
Cont. Var. & OY & $\rightarrow$ & CGL & -.048 & 1.448 & \\
Cont. Var. & RVN & $\rightarrow$ & CGL & .034 & 1.005 & .408 \\
Cont. Var. & NSTFF & $\rightarrow$ & CGL & .013 & .45 \\
\hline
\end{tabular}

Notes: BKS: Bookkeeping system; FR: Efficacy of Financial reporting; TAS: Adoption of Turkish Accounting Standards; BS: Efficacy of the Budgeting System; CGL: Corporate Governance Level; OY: Number of operating years; RVN: Revenue; NSTFF: Number of staff members; CR: Composite reliability

$* * * p<.01 ; * * p<.05$ 


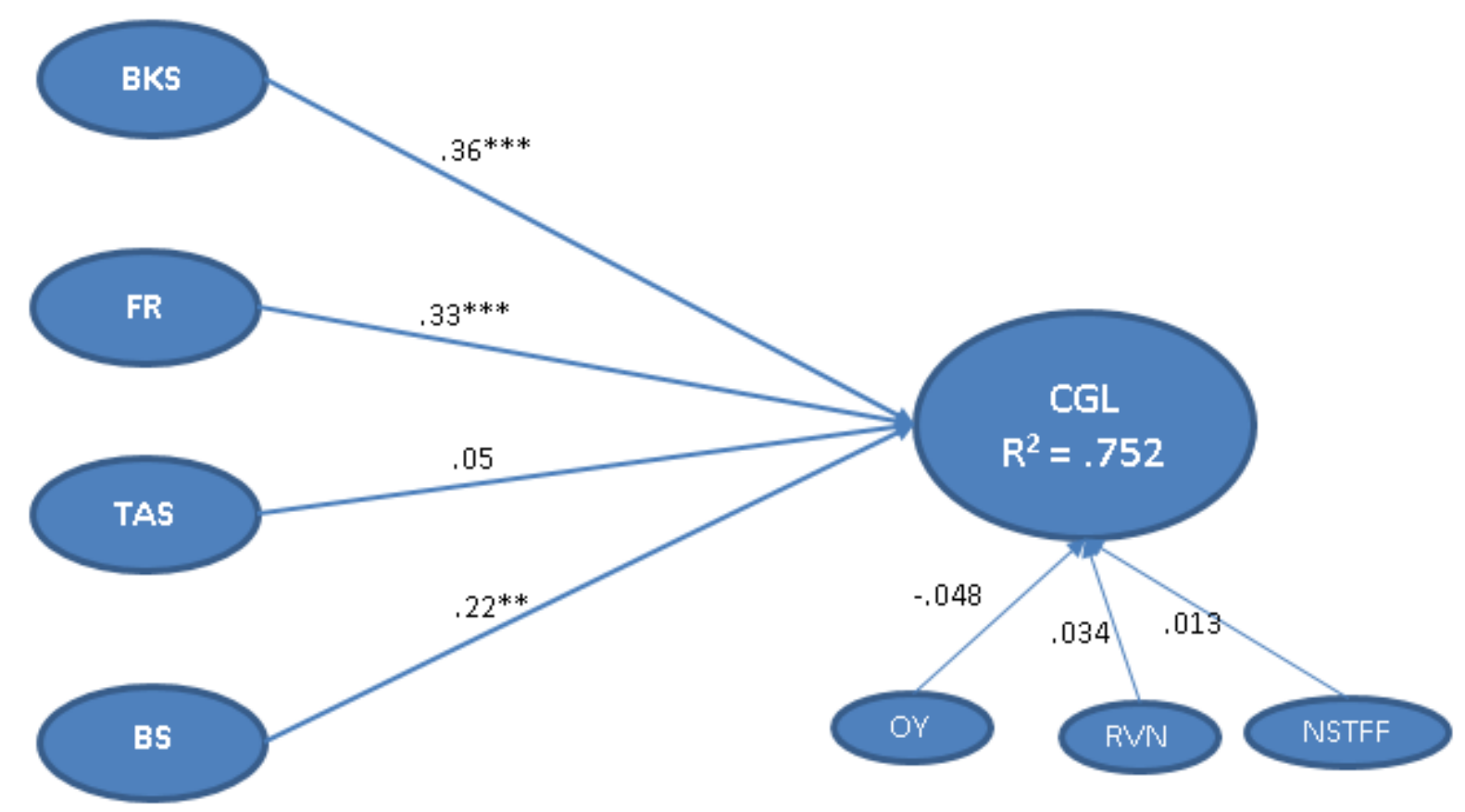

Figure 2: Path coefficients.

Notes: ${ }^{*} \mathrm{p}<.10 ;{ }^{*} \mathrm{p}<.05 ; * * \mathrm{p}<.01$. BKS: Bookkeeping system; FR: Efficacy of Financial reporting; TAS: Adoption of Turkish Accounting Standards; BS: Efficacy of the Budgeting System; CGL: Corporate Governance Level; OY: Number of operating years; RVN: Revenue; NSTFF: Number of staff members

Explanatory power: In models using PLS-SEM as a base, Chin (1998) recommends evaluating the explanatory power, the predictive relevance, and the predictive power. Table 5 shows the predictive relevance $\left(Q^{2}\right)$, goodness of fit index $(\mathrm{GoF})$, and the explained variance $\left(R^{2}\right)$. The value of the explained variance $\left(R^{2}\right)$ of the dependent construct enabled us to determine the explanatory power. According to Chin (1998), the threshold values for $R^{2}$ ranges are: substantial (.67), moderate (.33), and weak (.19). Since the $R^{2}$ value of corporate governance level is $75.2 \%$ which indicates the extent to which the model explained dependent variable's variance. Therefore, the variance of corporate governance level was explained at a substantial level.

Predictive relevance: In addition to the explanatory power, the $Q^{2}$ test (Stone, 1974; Geisser, 1975) was used to assess the predictive relevance of the model for fit. It measures the successful reconstruction of the observed values of the model and its parameter estimates (Chin, 1998). The blindfolding method is used to calculate the $Q^{2}$ value by omitting one case at a time and then reestimating the model parameters for the rest of the cases. Finally, the omitted case values are predicted, based upon the remaining parameters. Positive $\left(Q^{2}>0\right)$ values indicate that the model has a predictive relevance while negative $\left(Q^{2}<0\right)$ values represent that the model has no predictive relevance. Therefore, the highest $Q^{2}$ values showed the highest level of predictive relevance of the model. The predictive relevance of the corporate governance level was positive $(48.7 \%)$, which indicated that the endogenous latent variable of the proposed model had a predictive relevance (Table 5). The GoF (Goodness of fit) index, developed by Tenenhaus et al. (2004), was employed to determine the overall prediction performance of the model. It is calculated by the geometric mean of the average communality index and the average $R^{2}$ value. 
The GoF index of the proposed model was $80.8 \%$, which indicated that the model took $80.8 \%$ of the achievable fit into account (Table 5).

Table 5: The explained variance and predictive relevance values of the corporate governance level

\begin{tabular}{lrrrr}
\hline Total & SSO & SSE & $Q^{2}$ & $\mathrm{R}^{2}$ \\
\hline Corporate Governance Level & 1846.000 & 947.418 & .487 & .775 \\
GoF & .808 & & & \\
\hline
\end{tabular}

Notes: SSO: Sum of the Squared Observation; SSE: Sum of the squared prediction errors. GoF $=\sqrt{\overline{\overline{C o m}} \times \overline{\overline{R^{2}}}}$;

The $f^{2}$ effect size, as well as the $q^{2}$ effect size is related to the explained variance $\left(R^{2}\right)$ with predictive relevance $\left(Q^{2}\right)$ respectively. The value of $f^{2}$ indicates the extent to which the particular predecessor latent variable has a predictive value (effect size) in producing the $R^{2}$ for the dependent variable. Similarly, the value of $q^{2}$ indicates the extent to which the particular predecessor latent variable has a predictive relevance (effect size) in producing the $Q^{2}$ for the dependent variable. Therefore, the effect size is a measure to determine the effect of a particular predictor construct on an endogenous latent variable. The $f^{2}$ and $q^{2}$ evaluated the changes in the $R^{2}$ and in $Q^{2}$ respectively when the specified predecessor exogenous latent variable was eliminated from the model in order to show whether the eliminated variable had a significant impact on the $R^{2}$ and $Q^{2}$ values of the specific endogenous variable. The effect sizes for $f^{2}$ and $q^{2}$ values associated with the explained variance $\left(R^{2}\right)$ and with the predictive relevance $\left(Q^{2}\right)$ respectively. They are categorized (Cohen, 1988) as small (.02 - .14), medium (.15 - .34), and large (above .35). Table 6 shows the $f^{2}$ and $q^{2}$ effect sizes where the endogenous variable was the corporate governance level. According to the results, the bookkeeping system had a medium size effect in producing $R^{2}$ values for the corporate governance level, while the efficacy of financial reporting as well as the budgeting system had only a small effect. Moreover, the bookkeeping system, the efficacy of financial reporting and the budgeting system had a small effect in producing the predictive relevance $\left(Q^{2}\right)$ for the corporate governance level.

Table 6: Effect sizes of the Corporate Governance Level

\begin{tabular}{|c|c|c|c|c|c|c|}
\hline Predecessor Latent Variables & $R_{\text {Included }}^{2}$ & $R_{\text {Excluded }}^{2}$ & $f^{2}$ & $Q_{\text {Included }}^{2}$ & $Q_{\text {Excluded }}^{2}$ & $q^{2}$ \\
\hline $\mathrm{BKS}$ & .775 & .728 & .209 & .487 & .457 & .059 \\
\hline FR & .775 & .748 & .120 & .487 & .471 & .031 \\
\hline TAS & .775 & .774 & .004 & .487 & .486 & .001 \\
\hline BS & .775 & .762 & .058 & .487 & .479 & .015 \\
\hline OY & .775 & .773 & .009 & .487 & 485 & .003 \\
\hline RVN & .775 & .774 & .004 & .487 & .486 & .001 \\
\hline NSTFF & .775 & .775 & .000 & .487 & .487 & .001 \\
\hline
\end{tabular}

Notes: BKS: Bookkeeping system; FR: Efficacy of Financial reporting; TAS: Adoption of Turkish Accounting Standards; BS: Efficacy of the Budgeting System; CGL: Corporate Governance Level; OY: Number of operating years; RVN: Revenue; NSTFF: Number of staff members;

The effect size was evaluated using $q^{2}=\frac{Q_{\text {Included }}^{2}-Q_{\text {Excluded }}^{2}}{1-Q_{\text {Included }}^{2}} ; f^{2}=\frac{R_{\text {Included }}^{2}-R_{\text {Excluded }}^{2}}{1-R_{\text {Included }}^{2}}$;

\section{Conclusion}

This study aimed at investigating the association between the accounting information system (i.e. bookkeeping, financial reporting, the Turkish Accounting/Financial Reporting Standards, and budgeting system) and corporate governance. We assume that the findings of this study will contribute towards the enhancement of good corporate governance that alleviates agency problems in business organizations. The results of the empirical analyses indicated that 
bookkeeping system, efficacy of financial reporting, and efficacy of the budgeting system have a positive impact on the corporate governance level, whereas the mere adoption of Turkish Accounting/Financial Reporting Standards do not.

The findings have several implications regarding board members, managers, and organizations. Establishing corporate governance mechanisms and resolving agency issues are among the boards' primary responsibilities. In this respect, they are expected to support managers and help them design an accounting information system so as to foster the employment of corporate governance mechanisms. In order to ensure this, managers should establish internal reporting procedures, and internal control and monitoring devices before inviting external control through independent auditing. Therefore, sufficient and necessary steps have to be taken from the very initial bookkeeping stage of financial transactions until the ultimate financial reporting process to ensure the delivery of quality financial information to their stakeholders.

Moreover, the contribution of management accounting techniques (i.e. budgeting) to corporate governance should not be underestimated, as indicated by the empirical evidence. In particular, they are important for the allocation of resources appropriately, preventing the misuse of the financial and nonfinancial resources of the company, and generating value for their shareholders. One significant effect of the budgeting system on corporate governance underlines the implication that boards should give emphasis to management accounting practices, such as budgeting, to ensure internal monitoring practices, together with external reporting and monitoring. External reporting is an "end", whereas internal reporting and controlling tools are "means". Thus, in order to ensure the quality of external reporting, the means are expected to facilitate operations in a timely manner. However, it is assumed that boards do not demand sufficient emphasis on the utilization of management accounting in decision making (Mayanja and Van der Poll, 2011). Thus, the subject should be dealt with at the board level more seriously.

There are implications for academics as well. Prior studies have mainly focused on the role of financial reporting and auditing in corporate governance, rather than management accounting. Ratnatunga and Alam (2011) also pointed out that the utilization of management accounting practices in strategic governance is barely mentioned in the relevant empirical studies. Thus, more studies are required regarding the influence of management accounting practices on corporate governance. As for the limitation of the study, we can say that the sample size is not large enough, thus, the reader should employ caution in terms of generalizing the results.

\section{References:}

Abraham A, Deo H., \& Irvine H. (2008). What lies beneath? Financial reporting and corporate governance in Australian banks. Asian Review of Accounting, 16(1), 4-20. https://doi.org/10.1108/13217340810872445

Acar D., \& Özçelik H. (2011). Muhasebe bilgi kalitesini etkileyen kritik başarı faktörleri. Muhasebe ve Finansman Dergisi, 49, 10-23.

Afrifa, G. A., Tauringana, V. (2015). Corporate governance and performance of UK listed small and medium enterprises. Corporate Governance, 15(5), 719-733. https://doi.org/10.1108/CG-03-2015$\underline{0029}$

Alp A., \& Ustuntag S. (2009). Financial reporting transformation: the experience of Turkey. Critical Perspectives on Accounting, 20(5), 680-699. https://doi.org/10.1016/i.cpa.2007.12.005 
Alpay G., Bodur M., Yılmaz C., Çetinkaya S., \& Arıkan L. (2008). Performance implications of institutionalization process in family-owned businesses: Evidence from an emerging economy. Journal of World Business, 43, 435-448. https://doi.org/10.1016/j.jwb.2008.03.006

Anderson, J.C., \& Gerbing, D.W. (1988). Structural equation modeling in practice: a review and recommended two-step approach. Psychological Bulletin, 103(3), 411-423. https://doi.org/10.1037/0033-2909.103.3.411

Ankarath, N., Mehta K. J., Ghosh, T. P., \& Alkafaji, Y. A. (2010). Understanding IFRS fundamentals, John Wiley \& Sons Inc., New Jersey, United States.

Arora, A., Sharma, C. (2016). Corporate governance and firm performance in developing countries: evidence from India. Corporate Governance, 16(2), 420-436. https://doi.org/10.1108/CG-01-2016$\underline{0018}$

Arunruangsirilert, T., \& Chonglerttham, S. (2017). Effect of corporate governance characteristics on strategic management accounting in Thailand. Asian Review of Accounting, 25(1), 85-105. https://doi.org/10.1108/ARA-11-2015-0107

Australian Securities and Investments Commission. (2012). CLERP 9: Corporate reporting and disclosure laws; last accessed on 16 February 2012: http:// www.asic.gov.au/clerp9.

Bagozzi, R.P., \& Youjae, Yi. (1988). On the evaluation of structural equation models. Journal of the Academy of Marketing Science, 16, 74-94. https://doi.org/10.1007/BF02723327

Ball, R. (2006). International financial reporting standards (IFRS): Pros and cons for investors. Accounting and Business Research, 5 (27), 5-27. https://doi.org/10.1080/00014788.2006.9730040

Bokpin, G.A., \& Isshaq, Z. (2009). Corporate governance, disclosure and foreign share ownership on the Ghana stock exchange. Managerial Auditing Journal, 24(7), 688-703. https://doi.org/10.1108/02686900910975387

Bushman R., Chen, Q., Engel, E., \& Smith, A. (2004). Financial accounting information, organizational complexity and corporate governance systems. Journal of Accounting and Economics, 37, 167201. https://doi.org/10.1016/j.jacceco.2003.09.005

Bushman, R.M., \& Smith, A.J. (2001). Financial accounting information and corporate governance. Journal of Accounting and Economics, 32, 237-333. https://doi.org/10.1016/S0165$\underline{4101(01) 00027-1}$

Chen, X., Sun, Y., Xu, X. (2016). Free cash flow, over-investment and corporate governance in China. Pacific-Basin Finance Journal, 37, 81-103. https://doi.org/10.1016/.j.pacfin.2015.06.003

Chin, W.W. (1998). The partial least squares approach for structural equation modeling. In G. A. Marcoulides (Ed.), Modern methods for business research. (pp. 295-336). Mahwah, N.J.: Lawrence Erlbaum Associates.

Cohen, J. (1988). Statistical power analysis for the behavioral sciences. Lawrence Erlbaum Associates, Inc., $2^{\text {nd }}$ Edition.

Collins DW, De Angelo L. 1990. Accounting Information and Corporate Governance: Market and Analyst Reactions to Earnings of Firms Engaged in Proxy Contests. Journal of Accounting and Economics, 13: 213-247. https://doi.org/10.1016/0165-4101(90)90032-Y 
Uyar, Gungormus \& Kuzey | Impact of the Accounting Information System on Corporate Governance: Evidence from Turkey

Dinç, E., \& Abdioğlu, H. (2009). İşletmelerde kurumsal yönetim anlayışı ve muhasebe bilgi sistemi ilişkisi: İMKB-100 şirketleri üzerine ampirik bir araştırma. Balıkesir Üniversitesi Sosyal Bilimler Enstitüsü Dergisi, 12(21), 157-184.

Dinç, E., \& Varıcı, İ. (2008). Muhasebe bilgi sisteminin kurumsallaşma düzeyine etkisi: Sanayi işletmeleri üzerine bir araştırma. Afyon Kocatepe Universitesi IIIBF Dergisi, 10(1), 67-85.

Dumontier, P., \& Raffournier, B. (1998). Why firms comply voluntarily with IAS: An empirical analysis with Swiss data. Journal of International Financial Management and Accounting, 9(3), 216245. https://doi.org/10.1111/1467-646X.00038

Eng, L.L., \& Mak, Y.T. (2003). Corporate governance and voluntary disclosure. Journal of Accounting and Public Policy, 22(4), 325-345. https://doi.org/10.1016/S0278-4254(03)00037-1

Epstein, B. J., \& Jermakowicz, E. K. (2007). International standards for small and medium-sized entities, CPA Journal, 77 (10), 38-40.

EY (2010), Conceptual framework: objectives and qualitative characteristics, downloaded from http://www.ey.com/Publication/vwLUAssets/Supplement_86_GL_IFRS/\$FILE/Supplement_86_ GL_IFRS.pdf (accessed 04.12.2014).

Fornell, C., \& Larcker, D.F. (1981). Evaluating structural equation models with unobservable variables and measurement error. Journal of Marketing Research, 18(1), 39-50. https://doi.org/10.2307/3151312

Garry, D., Carnegie, G. D., \& O’Connell, B.T. (2014). A longitudinal study of the interplay of corporate collapse, accounting failure and governance change in Australia: Early 1890s to early 2000s. Critical Perspectives on Accounting, 25, 446-468. https://doi.org/10.1016/i.cpa.2013.04.001

Geisser, S. (1975). The predictive sample reuse method with applications. Journal of American Statistical Association, 70, 320-328. https://doi.org/10.1080/01621459.1975.10479865

Güngörmüş, A. H. (2014). Küçük ve Orta Ölçekli İşletmelerin Bağımsız Denetime yaklaşımlarını Etkileyen Faktörler Üzerine Bir Araştırma. Basılmamış (Unpublished doctoral thesis), Dumlupınar Üniversitesi, Kütahya, Turkey.

Hair, J. F., Jr Anderson, R. E, Tatham, R. L., \& Black, W. C. (2010). Multivariate data analysis with readings, 7 th Edn. Englewood Cliffs, NJ: Prentice Hall.

Hair, J. F., Hult, G. T. M., Ringle, C. \& Sarstedt, M. (2013). A Primer on Partial Least Squares Structural Equation Modeling (PLS-SE). Sage Publications, Inc.

Haniffa, R. M., \& Cooke, T. E. (2002). Culture, corporate governance and disclosure in Malaysian corporations. Abacus, 38 (3), 317-349. https://doi.org/10.1111/1467-6281.00112

Hu, L., \& Bentler, P. M. (1999). Cutoff criteria for fit indexes in covariance structure analysis: Conventional criteria versus new alternatives. Structural Equation Modeling, 6(1), 1-55. https://doi.org/10.1080/10705519909540118

Jarvis, C. B., Mackenzie, S. B., \& Podsakoff, P. M. (2003). A critical review of construct indicators and measurement model misspecification in marketing and consumer research. Journal of Consumer Research, 30, 199-218. https://doi.org/10.1086/376806 
Jeanjean, T., \& Stolowy, H. (2008). Do accounting standards matter? An exploratory analysis of earnings management before and after IFRS adoption. Journal of Accounting and Public Policy, 27(6), 480-494. https://doi.org/10.1016/j.jaccpubpol.2008.09.008

Jones, S., \& Finley, A. (2011). Have IFRS made a difference to intra-country financial reporting diversity? British Accounting Review, 43(1), 22-38. https://doi.org/10.1016/j.bar.2010.10.004

Joshi, P. L., \& Ramadhan, S. (2002). The adoption of international accounting standards by small and closely held companies: Evidence from Bahrain. International Journal of Accounting, 37(4), 429-440. https://doi.org/10.1016/S0020-7063(02)00190-5

Kalbers, L. P. (2009). Fraudulent financial reporting, corporate governance and ethics: 1987-2007. Review of Accounting and Finance, 8(2), 187 - 209. https://doi.org/10.1108/14757700910959510

Kılıç, M., Uyar, A., \& Ataman. B. (2014). Preparedness for and perception of IFRS for SMEs: evidence from Turkey. Accounting and Management Information Systems, 13(3), 492-519.

Madawaki, A. (2012). Adoption of international financial reporting standards in developing countries: The case of Nigeria. International Journal of Business and Management, 7(3), 152-161. https://doi.org/10.5539/ijbm.v7n3p152Mayanja, M. K., \& Van der Poll, H. M. (2011). Management accounting: An instrument for implementing effective corporate governance. African Journal of Business Management, 5(30), 12050-12065. https://doi.org/10.5897/AJBM11.1232

Naumann, K. P. (2000). Financial reporting enforcement mechanisms as an element of corporate governance in Germany and reflections on their further development. The European Accounting Review, 9(4), 655-672. https://doi.org/10.1080/09638180020024043

Neag, R., Maşca, E., \& Paşcan, I. (2009). Actual aspects regarding the IFRS for SMEs - Opinions, debates and future developments. Annales Universitatis Apulensis Series Oeconomica, 11(1), $32-42$.

Nobes, C., \& Stadler C. 2(013). How arbitrary are international accounting classifications? Lessons from centuries of classifying in many disciplines, and experiments with IFRS data. Accounting, Organizations and Society, 38, 573-595. https://doi.org/10.1016/i.aos.2013.10.001

Nunnally, J. (1978). Psychometric theory, 2nd Edn. New York: McGraw-Hill.

Pallisserry, F. (2012). True and fair financial reporting: a tool for better corporate governance. Journal of Financial Crime, 19(4), 332-342. https://doi.org/10.1108/13590791211266331

Ratnatunga, J., \& Alam, M. (2011). Strategic governance and management accounting: evidence from a case study. Abacus, 47(3), 343-382. https://doi.org/10.1111/j.1467-6281.2011.00344.x

Seal, W. (2006). Management accounting and corporate governance: An institutional interpretation of the agency problem. Management Accounting Research, 17, 389-408. https://doi.org/10.1016/j.mar.2006.05.001

Shil, N. C. (2008). Accounting for good corporate governance, JOAAG, 3(1), 22-31.

Sloan, R. G. (2001). Financial accounting and corporate governance: a discussion. Journal of Accounting and Economics, 32, 335-347. https://doi.org/10.1016/S0165-4101(01)00039-8

Stone, M. (1974). Cross-validatory choice and assessment of statistical predictions. Journal of the Royal Statistical Society, Series B (Methodological), 36(2), 111-147. 
Tenenhaus, M., Amato, S., \& Esposito Vinzi V. (2004). A global goodness-of-fit index for PLS structural equation modelling. Proceedings of the XLII SIS Scientific Meeting, 1, 739-742.

Tsamenyi, M., Enninful-Adu, E., \& Onumah, J. (2007). Disclosure and corporate governance in developing countries: Evidence from Ghana. Managerial Auditing Journal, 22 (3), 319-334. https://doi.org/10.1108/02686900710733170

Uyar, A., \& Güngörmüş, A. H. (2013). Perceptions and knowledge of accounting professionals on IFRS for SMEs: evidence from Turkey. Research in Accounting Regulation, 25, 77-87. https://doi.org/10.1016/j.racreg.2012.11.001

Uyar, A. (2012). Determinants of corporate reporting on the internet: an analysis of companies listed on the Istanbul Stock Exchange. Managerial Auditing Journal, 27(1), 87-104. https://doi.org/10.1108/02686901211186117

Uyar, A., Kılıç, M., \& Gökçen, B. A. (2016). Compliance with IAS/IFRS and firm characteristics: evidence from the emerging capital market of Turkey. Economic Research-Ekonomska Istraživanja, 29(1), 148-161. https://doi.org/10.1080/1331677X.2016.1163949

Uyar, A., Kuzey, C. (2016). Contingent Factors, Extent of Budget Use and Performance: A Structural Equation Approach. Australian Accounting Review, 26(1), 91-106. https://doi.org/10.1111/auar.12090

Wang, D. H. M., \& Huynh, Q. L. (2014). The Role of Corporate Governance in the Link between Management Accounting System and Firm Performance. Asian Journal of Finance \& Accounting, 6(1), 216-235. https://doi.org/10.5296/ajfa.v6i1.5159 


\section{QUESTIONNAIRE SURVEY}

\begin{tabular}{|c|c|}
\hline Name of the Organization & \\
\hline Number of staff (NSTFF) & ( ) $0-9$ ( ) 10-49 ( ) $50-99$ ( ) 100-249 ( ) more than 250 \\
\hline Operating years $(\mathrm{OY})$ & $\begin{array}{l}\text { ( ) less than } 10 \text { years ( ) } 10-19 \text { years ( )20-29 years } \\
\text { ( ) 30-39 years ( ) more than } 40 \text { years }\end{array}$ \\
\hline Sector for providing service & ( ) Only domestic market ( ) Only international market ( ) Both \\
\hline Revenue (RVN) & $\begin{array}{l}\text { ( ) Less than 1.000.000 TRY } \\
\text { ( ) Between } 1.000 .000-8.000 .000 \mathrm{TRY} \\
\text { ( ) Between } 8.000 .001-40.000 .000 \mathrm{TRY} \\
\text { ( ) Between } 40.000 .001-80.000 .000 \mathrm{TRY} \\
\text { ( ) Between } 80.000 .001-100.000 .000 \mathrm{TRY} \\
\text { ( ) More than } 100.000 .001 \mathrm{TRY}\end{array}$ \\
\hline $\begin{array}{l}\text { Number of senior managers } \\
\text { outside family member }\end{array}$ & $\begin{array}{l}\text { ( ) None ( ) } 1-3 \text { persons ( ) } 4-6 \text { persons } \\
\text { ( ) 7-9 persons ( ) more than } 10 \text { persons }\end{array}$ \\
\hline Education level & $\begin{array}{l}\text { ( ) Secondary school ( ) High school ( ) 2-year vocational school ( ) } \\
\text { Faculty () Master degree/PhD }\end{array}$ \\
\hline
\end{tabular}

\begin{tabular}{|c|c|c|c|c|c|c|}
\hline & $\begin{array}{l}\text { Accounting Information System } \\
\text { Evaluate the following statements by considering the applications } \\
\text { in your firm. }\end{array}$ & 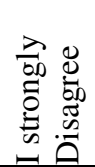 & 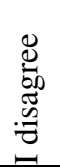 & 苛 & 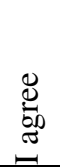 & 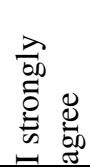 \\
\hline BKS1 & $\begin{array}{l}\text { Policies and procedures on how to record the accounting } \\
\text { transactions are established in the firm. }\end{array}$ & & & & & \\
\hline BKS2 & $\begin{array}{l}\text { The staff who record the transactions and verify them are always } \\
\text { different. }\end{array}$ & & & & & \\
\hline BKS3 & $\begin{array}{l}\text { The documents are always signed by the preparers and receivers of } \\
\text { those documents. }\end{array}$ & & & & & \\
\hline BKS4 & $\begin{array}{l}\text { Procedures are established regarding how to use the existing } \\
\text { accounts. }\end{array}$ & & & & & \\
\hline FR1 & $\begin{array}{l}\text { In addition to mandatory (legal) financial reports, supplementary } \\
\text { financial reports are prepared in the firm. }\end{array}$ & & & & & \\
\hline FR2 & $\begin{array}{l}\text { At the end of the year, financial analysis reports are prepared and } \\
\text { used in decision-making process. }\end{array}$ & & & & & \\
\hline FR3 & $\begin{array}{l}\text { Management uses the information on financial reports in } \\
\text { performance evaluation. }\end{array}$ & & & & & \\
\hline TAS1 & $\begin{array}{l}\text { The transactions are recorded according to Turkish Accounting } \\
\text { Standards. }\end{array}$ & & & & & \\
\hline TAS2 & $\begin{array}{l}\text { Financial reports are prepared in line with Turkish Financial } \\
\text { Reporting Standards. }\end{array}$ & & & & & \\
\hline BS1 & $\begin{array}{l}\text { Existence of a separate unit regarding budgeting enables better } \\
\text { planning and controlling in the company. }\end{array}$ & & & & & \\
\hline $\mathrm{BS} 2$ & Operating budgets are regularly prepared and revised if necessary. & & & & & \\
\hline BS3 & Operating budgets are used in managerial decision-making. & & & & & \\
\hline
\end{tabular}


Uyar, Gungormus \& Kuzey | Impact of the Accounting Information System on Corporate Governance: Evidence from Turkey

\begin{tabular}{|c|c|c|c|c|c|c|}
\hline & $\begin{array}{l}\text { Corporate Governance } \\
\text { Evaluate the following statements by considering the } \\
\text { applications in your firm. }\end{array}$ & 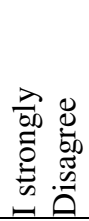 & 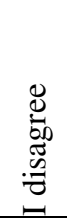 & 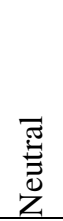 & 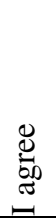 & 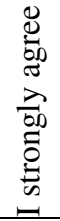 \\
\hline CG1 & Medium and long-term plans are shared with employees & & & & & \\
\hline CG2 & Employees know the organization's goals clearly & & & & & \\
\hline CG3 & Individual departures do not jeopardize business operations & & & & & \\
\hline CG4 & $\begin{array}{l}\text { We have productive meetings where everyone has an equal } \\
\text { saying }\end{array}$ & & & & & \\
\hline CG5 & $\begin{array}{l}\text { In internal auditing, besides the family members we also } \\
\text { include the department heads and specialists in the assessment } \\
\text { process }\end{array}$ & & & & & \\
\hline CG6 & $\begin{array}{l}\text { Job descriptions, rights and responsibilities of employees are } \\
\text { written }\end{array}$ & & & & & \\
\hline CG7 & We have a succession plan for every top manager & & & & & \\
\hline CG8 & Meetings have planned agendas & & & & & \\
\hline CG9 & $\begin{array}{l}\text { We have specific written codes of behavior for organizational } \\
\text { processes and for the relationship among the departments }\end{array}$ & & & & & \\
\hline CG10 & We have a predefined system for decision-making & & & & & \\
\hline CG11 & We have written job descriptions for every position. & & & & & \\
\hline CG12 & We always keep record of the things discussed in our meetings & & & & & \\
\hline CG13 & There is a fair remuneration policy of the company & & & & & \\
\hline CG14 & Objective criteria are used in personnel selection & & & & & \\
\hline CG15 & Everyone's performance is fairly assessed & & & & & \\
\hline CG16 & Employee selection is done based on positional requirements & & & & & \\
\hline CG17 & $\begin{array}{l}\text { Everyone's performance is assessed based on clearly defined } \\
\text { and written rules }\end{array}$ & & & & & \\
\hline
\end{tabular}

